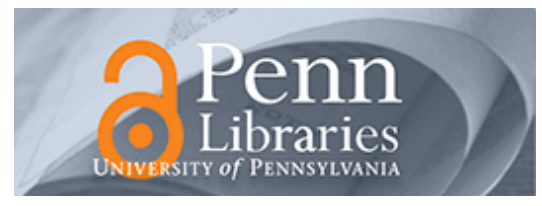

University of Pennsylvania

ScholarlyCommons

\title{
Failing Those at Ground Zero... Again: American Public Health Responses to AIDS and 9/11
}

\author{
Autumn Fiester \\ University of Pennsylvania, fiester@mail.med.upenn.edu \\ Lance Wahlert \\ University of Pennsylvania, Iwahlert@sas.upenn.edu
}

Follow this and additional works at: https://repository.upenn.edu/bioethics_papers

Part of the Medicine and Health Sciences Commons

\section{Recommended Citation}

Fiester, A., \& Wahlert, L. (2011). Failing Those at Ground Zero... Again: American Public Health Responses to AIDS and 9/11. Retrieved from https://repository.upenn.edu/bioethics_papers/71

Suggested Citation:

Wahlert, L. and Fiester, A . , "Failing Those at Ground Zero... Again: American Public Health Responses to AIDS and 9/11, American Journal of Bioethics, Volume 11, No. 9, September 2011: 1-2 .

\section{Preprint version.}

This is an electronic version of an article published in American Journal of Bioethics. American Journal of Bioethics is available online at: http://www.tandfonline.com/doi/pdf/10.1080/15265161.2011.613254

This paper is posted at ScholarlyCommons. https://repository.upenn.edu/bioethics_papers/71

For more information, please contact repository@pobox.upenn.edu. 


\section{Failing Those at Ground Zero... Again: American Public Health Responses to AIDS and $9 / 11$}

\section{Disciplines}

Medicine and Health Sciences

\section{Comments}

Suggested Citation:

Wahlert, L. and Fiester, A . , "Failing Those at Ground Zero... Again: American Public Health Responses to AIDS and 9/11, American Journal of Bioethics, Volume 11, No. 9, September 2011: 1-2 .

Preprint version.

This is an electronic version of an article published in American Journal of Bioethics. American Journal of Bioethics is available online at: http://www.tandfonline.com/doi/pdf/10.1080/15265161.2011.613254 


\section{Editorial}

\section{Failing Those at Ground Zero... Again: American Public Health Responses to AIDS and 9/11}

What can one say in the wake of tragedy? Certainly, in the first weeks after 9/11, there was no shortage of voices expressing sympathy, outrage, worry, and caution. Grappling with the enormity of the event seemed to necessitate from each of us personal expressions of corresponding magnitude. LGBT persons, especially those living in New York City, were no exception.

Consider the following from a resident of Manhattan's Lower East Side submitted to a regional queer magazine just days after 9/11: "This might be the worst thing imaginable to happen to [NYC]. We've lost so much in just the past few days... And so we must reach out to one another again."

What is initially most striking about the sentiments in this statement is that they read as so universal for all survivors of the $9 / 11$ tragedy. The hurt, the anguish, the complete lack of direction in a world and in a city that changed radically on what seemed to be a typical morning.

But what strikes even more resonantly, perhaps, is the single word "again." The devastating scale of the $9 / 11$ tragedy cannot be underestimated, but its uniqueness as a catastrophic blow to the security, safety, and health of New Yorkers in particular is not the first of its kind. And LGBT persons (like many others) have felt this profoundly.

Historically, lower Manhattan has seen its share of epidemiological and public health tragedies over the years: the yellow fever epidemic of 1795 that spread from nearby Philadelphia, the global cholera pandemic that devastated New York City in 1832, health safety violations that littered the island's garment and financial districts during the early twentieth century, and small pox outbreaks dating back to the city's founding through the middle of the twentieth century. But for LGBT persons living in New York City (and beyond its reaches), it is the recent memory (and still present specter) of AIDS that informs this post-9/11 feeling of "again."

Over the past ten years, many media outlets and many of us have referred to the events of a decade ago as a "day that changed the world." The gravity and succinctness of that heading isolates its temporal starting point on 9/11/2001. By 
implication then, it takes as its geographic epicenter Ground Zero, located in NYC's Battery Park. But for LGBT persons in New York and beyond, grappling with the magnitude of that horrific event ten years ago and since, there are familiar feelings of tragedy, fatality, and fear-ones that identify more than one Ground Zero, and more than one day that changed the face and the health of its queer citizens.

In fact, geographically, if we travel just a few dozen blocks north of Ground Zero (five subway stops uptown on the 1/9 line), we find ourselves at Christopher Street in the heart of the West Village, where gays, lesbians, and trans persons have made a home for themselves for generations long before they populated en masse in Chelsea, Midtown, Williamsburg, and beyond. Here is where the Stonewall Riots of 1969 revived and added vitriol to the gay civil rights movement. Temporally, travelling 25 or 30 years into the past from today and into that very neighborhood and its surrounding areas, we find ourselves at another site of injury - where AIDS first made itself known in gay communities. Accordingly, for LGBT persons, downtown Manhattan has endured as a site of Ground Zeros - in the early 1980s, on 09/11, and today.

History has shown, of course, that the Ground Zero of the HIV/AIDS epidemic was both a tragic site of illness and dying, as well as the epicenter of an outcry about the failure of American public health institutions to rally to the side of those devastated by the disease. A virus, at the time almost universally fatal, that had been unleashed on American citizens brought only scorn, blame, and denial. The first decade of the public health response to the AIDS crisis is marred by a reluctance to treat, fund, research, and sympathize with those affected by this devastating illness. The stigma attached to gay men, the virus's first significant American victims, lead (on the one hand) to silence and inaction from the Reagan Administration in the face of CDC damage control efforts and (on the other) to one of the most virulent - and effective-activist campaigns to secure better therapies, easier healthcare access, and greater attention in fighting the disease.

But surely there could be no echoes of this earlier, protracted struggle in our recent attention to the healthcare needs of those ill at the Ground Zero of 9/11? The 9/11 First Responders were, after all, the undisputed heroes of that day and its aftermath, and they bore no parallel stigma of contagion, threat, or culpability to the early AIDS victims. Certainly, our collective debt to the First Responders would be repaid with a sharp departure from the way we failed the men dying 
in the early AIDS epidemic by providing the $9 / 11$ victims with the very best science, medicine, treatment, and monitoring we had to offer.

And yet we did not. Instead, we allowed our shameful record on public-financed healthcare to repeat itself. Early warnings that there was an imminent healthcare calamity in the wake of the attacks were ignored, downplayed, or squelched by the Bush and Giuliani Administrations-even the EPA doctored documents to minimize the likely risks. After the worst predictions of rampant respiratory illnesses and cancer came true, the government fought citizens' pleas for healthcare assistance for a decade, only passing the Zadroga Bill on the 10th anniversary of the attack.

Our collective hope is that there will be no future Ground Zeros. Certainly, 9/11 cannot simply be understood as a public health aftershock of the AIDS crisis. Nor can these two events ever be viewed as synonymous or even remotely interchangeable. But rather, they are two distinct moments united by common bonds of communal trauma and pathos, recalcitrance and remembrance. Accordingly, should there ever be another public health crisis of this magnitude-and, no doubt, there will be one someday - let the legacy of these two tragedies be a resolve to meet swiftly and effectively the healthcare needs of those on the front lines. Queer or not queer, heroes or ordinary citizens. Let us not fail the victims of public health crises in this way. Let us not fail them again.

\section{REFERENCES}

Environmental Protection Agency. 2003. EPA's response to the World Trade Center collapse: Challenges, successes, and areas for improvement. Available at: http://www.epa.gov/oig/reports/2003/WTC_report_20030821.pdf

Letters for us. 2001. P[i]nk. 5: 2.

Moreno, J.D. 2002. Bioethics after the terror. American Journal of Bioethics 2(1): 60-64.

New York State Department of Labor. 2006. Labor department remembers 95th anniversary of sweatshop fire. Available at: http://www.labor.state.ny.us/pressreleases/2006/ March21_2006.htm 
Rosenberg, C.E. 1987. The cholera years: the United States in 1832, 1849, and 1866. Chicago: University of Chicago Press.

Sepkowitz, K.A. 2004. The 1947 smallpox vaccination campaign in New York City, revisited. Emerging Infectious Diseases Report of the CDC. Available at: http://www.cdc.gov/ncidod/EID/vol10no5/03-0973.htm

Shilts, R. 1987. And the band played on: people, politics, and the AIDS epidemic. New York: St. Martin's Press.

Stolberg, S.G. 2011. 9/11 health bill signed into law by Obama. New York Times January 3, 2011: A17.

Warner, M. 1985. Hunting the yellow fever germ: the principle and practice of etiological proof in late nineteenth-century America. Bulletin of the History of Medicine 59(3): 361-9. 